DOI: $10.4274 /$ tpa.46.42

\title{
Ergenlerde görülen meme hastalıkları
}

Breast disorders in adolescents

Zeynep Şıklar

Ankara Üniversitesi Tıp Fakültesi, Pediatrik Endokrinoloji Bilim Dalı, Ankara, Türkiye

\section{Özet}

Ergenlerde görülen meme hastalıkları heterojen bir grubu oluşturmakta ve genellikle iyi huylu bozuklukları içermektedir. Asimetri, amasti, amazi, politeli, ateli gibi yapısal bozukluklar, juvenil hipertrofi, enfeksiyonlar (mastit, meme başı akıntısı, meme apsesi), ve kitleler ergen yaş grubunda görülebilir. Memede saptanan kitlelerin çoğu fibroadenomdur. Ergenlerde malign meme lezyonları nadirdir. Malign meme kitlelerinin çoğunu primer lezyondan çok metastatik lezyonlar oluşturur. (Türk Ped Arş 2011; 46 Özel Sayı: 85-7)

Anahtar sözcükler: Ergen, meme hastalıkları, meme kitleleri

\section{Summary}

Breast disorders in adolescents constitute a heterogeneous group of lesions, and usually include benign lesions. Developmental disorders such as asimetry, amastia, amasia, athelia, polythelia; juvenil hyperthrophy, inflammatory disorders (mastitis, nipple discharge, breast abcess), and mass lesions can be seen in the adolescent age group. Fibroadenoma is the most common lesion of the breast. Malignant lesions of the breast in adolescents are rare. Malignant breast masses more commonly result from metastases than from primary lesions. (Turk Arch Ped 2011; 46 Suppl: 85-7)

Key words: Adolescents, breast disorders, breast masses

\section{Giriş}

Ergenlik evresinde meme hastalıkları hem birey hem de ailesi için endişe kaynağı olabilen, ancak genellikle iyi huylu sorunlardan oluşmaktadır. Yapısal bozukluklar gibi çoğu sorunlar sadece fizik inceleme ile tanınır. Süregen ya da artan sorunlarda ayrıntılı inceleme gerekmektedir.

Meme gelişimi embriyolojik 4. haftadan sonra görülmeye başlar. Ektodermden kaynaklanan süt çizgileri (=süt kıvrımı, meme kıvrımı, mammary ridge) embryolojik 5-6. haftada ön karın duvarında belirir ve pektoral bölgedekiler hariç giderek geriler. Östrojen süt kanallarını ve fibroadipoz dokuyu uyarırken, progesteron lobuler yapı ve alveolar tomurcuklanmayı uyarmaktadır (1).

Kızlarda meme dokusu 8-13 yaşları arasında büyümeye başlar ve yaklaşık 4 yıl içinde normal erişkin tipi meme dokusu oluşur. Kızlarda pubertenin ilk bulgusu telarş 13 yaşından sonra başlamazsa puberte gecikmesi açısından değerlendirme gerekir (2).

Ergenlik dönemi meme hastalıklarının önemli bir kısmını yapısal bozukluklar oluşturur.

\section{Memenin sayı ve yerleşim bozuklukları}

Embriyonik dönem süt kıvrımının gerilemesindeki sorunlar nedeniyle olur. Genellikle göğüs duvarı, vulva, aksilla gibi süt çizgisi hattında yer alır. Eğer süt çizgisi dışındaysa ektopik meme olarak adlandırılır. Fazla meme dokusunda sadece meme başı varsa politeli; areola ve glanduler doku varsa polimasti olarak adlandırımaktadır (1-3). 
Memenin yokluğu amasti ya da amazi şeklinde olabilir. Amasti hem areola hem glanduler meme dokusu yokluğu; amazi ise sadece glanduler doku yokluğu şeklindedir. Amasti ve amazi bazı doğumsal bozukluklara eşlik edebilir (3).

\section{Memenin şekil bozuklukları}

Meme hafif derecede asimetrik ise normal kabul edilebilir. Ciddi asimetri plastik cerrahi düzeltmeyi gerektirir. Asimetrinin nedeninin tek taraflı atrofi mi yoksa diğer tarafın hipertrofisi mi olduğu izlem ile ayırt edilmelidir (1).

Tüberöz meme nedeni bilinmeyen; meme tabanında sınırı büyüme, meme başı ve areolanın fazla gelişmesiyle karakterizedir. Glanduler doku genelde genişlemiş areolanın içindedir (4).

\section{Juvenil hipertrofi}

Pubertal ya da virjinal hipertrofi olarak da adlandırılan bu durum genellikle pubertal yaş grubunda görülmektedir. İyi huylu, bir ya da iki taraflı meme dokusunun artışı saptanır. Bazı ergenlerde meme dokusundaki büyüme çok fazla olabilir. Gonadotropinler ve östrojen düzeyi normaldir. Gereken olgularda meme büyümesi tamamlandıktan sonra cerrahi düzeltme uygulanabilir $(1,5)$.

\section{Meme başı akıntıları}

Ergenlik evresinde sık rastlanan bir durum olmadığı için, meme başı akıntıları varlığında ileri inceleme yapmak gerekebilir. Bu dönemde en sık görülen akıntı süt kıvamında görülen galaktoredir. Galaktore pubertenin ilk yıllarında kızlarda normal olabileceği gibi, ilaç kullanımına bağlı ya da prolaktinoma sonucu ortaya çıkabilir. Ergen gebeliği olasıı̆̆ı da akılda tutulmalıdır. Trisiklik antidepresanlar, fenotiyazin, metildopa ve risperidon galaktore yapabilen ilaçlar arasında yer alır (6).

Meme başı akıntısı kanlı, tek taraflı ve kendiliğinden ise önemsenmelidir.

\section{Meme enfeksiyonları}

Mastit en sık görülen meme dokusu enfeksiyonudur. Mastit iyileșmezse apse gelişebilir. Ergenlerde görülen mastitler genellikle meme başı çevresinde yer alır. Meme başı travmaları ise mastite neden olan en sık etkendir (6).

\section{Meme kitleleri}

Ergenlik evresinde memede saptanan kitlelerin çoğu fibroadenomdur. Fibroadenomlar genellikle puberte başladıktan sonra görülmeye başlar. Zamanla gerileme olmaz.

Glanduler doku ve stromadan zengin bu yapılar bazen çok büyüyebilir. Dev fibroadenom olarak adlandırıan büyük fibroadenomların yaklaşık \%10'u malign özellikte$\operatorname{dir}(2,5,7)$.

\section{Fillodes tümör}

Fibroepitelyal özellikte, nadir görülen kitlelerdir. Hızla büyüyebilir. Malignite eğilimi nedeniyle büyüyen kitlelerde geniş eksizyon yapılmalıdır. Histolojik olarak tanınır (8).

\section{Kistler}

Fibroadenomdan sonra en sık memede kitle nedeni basit kistlerdir. Duktal dilatasyon ile puberte başladıktan sonra görülmeye başlar. Menstruel döngü sırasında hızla büyüme ve menses sonunda sıklıkla kendiliğinden gerileme özelliğine sahiptir (5).

\section{Duktal ektazi}

Nadir görülen, meme başından kanlı akıntı yapabilen duktal ektazi genekllikle tek taraflıdır (5).

\section{Galaktosel}

Tipik olarak ağrısız büyüyen, sert olmayan kitle olarak ortaya çıkar. Tek ya da iki taraflıdır.

Gebelik sonrası daha sık olsa da ergenlik evresinde her iki cinste görülebilmektedir. Ultrasonografide lezyonun içinde sıvı-yağ seviyesi görünümü tipikdir. Aspirasyonda süt benzeri sıvı tanıyı kesinleştirir (5).

\section{Fibrokistik hastalık}

Görülme sıklı̆ı̆ı ergen yaş grubunda azdır. Birden fazla odakta, ağrılı olabilen noduller saptanır (1).

\section{Memenin malign hastalıkları}

Ergenlerde memede saptanan kitlenin malign olma olasılığı çok düşüktür. Memenin malign tümörleri primer meme kanserinden çok metastatik kanserlerdir. Metastatik meme malignitelerinin başında rabdomiyosarkom gelir. Ancak ailede meme kanseri öyküsü olanlarda primer meme kanseri olasılı̆̆ı daha yüksektir $(6,9)$.

Intraduktal ya da lobular infiltratif tip kanserlerde memeyi koruyan cerrahi (Lumpektomi) ve aksiller lenf nodu diseksiyonu + radyoterapi ya da modifiye radikal mastektomi uygulanması önerilmektedir. Sistemik adjuvan kemoterapi ise meme kanserli tüm ergenlere verilmelidir.

Tüm meme kanserlerinin $\% 5$ 'i ailesel meme kanseri grubundadır. Kalıtsal ailevi meme kanseri olan olgularda genellikle erken başlangıçı, iki taraflı ve çok odaklı meme kanseri saptanmaktadır. Bazı genler ya da hastalıklar meme kanseri sıklığını arttırmaktadır. Meme kanserine duyarısıı̆ı arttıran genler olan BCRA1 ve BCRA2 genlerini tașıyan 
bireylerde hayat boyu meme kanseri gelişme riski \%60-80'lere çıkmaktadır. Li-Fraumeni sendromu, Cowden hastalığı, ataxi telenjiektazi gibi hastalıklarda meme kanseri gelişme olasılığı yüksektir $(6,9,10)$.

\section{Kaynaklar}

1. Greydanus DE, Matytsina L, Gains M. Breast disorders in children and adolescents. Prim Care 2006; 33: 455-502. (Abstract)

2. Fallat ME, Ignacio RC. Breast Disorders in Children and Adolescents. J Pediatr Adolesc Gynecol 2008; 21: 311-6.

3. Guray M, Sahin A. Benign Breast Diseases: Classification, Diagnosis, and Management. The Oncologist 2006; 11: 435-49. (Abstract) / (Full Text) / (PDF)

4. Mandrekas AD, Zambacos GJ, Anastasopoulos A, Hapsas D, Lambrinaki N, loannidou-Mouzaka L. Aesthetic reconstruction of the tuberous breast deformity. Plast Reconstr Surg 2003 ; 112: 1099-108. (Abstract)
5. Chung EM, Cube R, Hal GJl, González C, Stocker JT, Glassman LM. Breast Masses in Children and Adolescents: Radiologic-Pathologic Correlation. RadioGraphics 2009; 29: 907-31. (Abstract) / (Full Text) / (PDF)

6. Meisner ALW, Fekrazad MH, Royce ME. Breast Disease: Benign and Malignant. Med Clin N Am 2008; 92: 1115-41. (Abstract) / (Full Text) / (PDF)

7. Ameryckx L, Leunen M, Wylock P, Amy JJ. Breast problems in children and adolescents. Eur Clinics Obstet Gynaecol 2005; 1: 151-63. (Abstract) / (PDF)

8. Cecen E, Uysal KM, Harmancıoglu Ö. Phyllodes tumor of the breast in an adolescent girl. Pediatr Hematol Oncology 2008; 25: 79-82. (Abstract)

9. Gutierrez JC, Housri N, Koniaris LG, Fischer AC, Sola JE. Malignant breast cancer in children: a review of 75 patients. J Surg Res 2008; 15: 182-8. (Abstract) / (Full Text) / (PDF)

10. D'Angelo $P$, Carli $M$, Ferrari $A$, et al. Breast metastases in children and adolescents with rhabdomyosarcoma: Experience of the Italian soft tissue sarcoma committee. Pediatr Blood Cancer 2010; 55: 1306-9. (Abstract) / (Full Text) / (PDF) 